\title{
Indigenous Healers and Stuttering
}

\author{
Rozanne Platzky and Joan Girson
}

\author{
Department of Speech Pathology and Audiology \\ University of the Witwatersrand
}

\begin{abstract}
Traditional beliefs and attitudes of Black South Africans to stuttering were investigated. Four Indigenous Healers (IHs) from different ethnic groups were interviewed about their beliefs as to cause and management of stuttering, as well as the outcome of their treatment. The data reveals varying degrees of concern about stuttering. The traditional beliefs of cause and management of stuttering show some similarities to current beliefs held by speech pathologists. Implications in terms of direction in therapy, cooperation with IHs and future research in this field are discussed.
\end{abstract}

\section{OPSOMMING}

Die tradisionele opvattings en houdings van Swart Suid-Afrikaners ten opsigte van hakkel is ondersoek. Onderhoude is met vier Tradisionele Genesers van verskillende etniese groepe gevoer om hulle geloofsoortuiginge te bepaal ten opsigte van die oorsaak en behandeling van hakkel, sowel as die resultate wat gekry word met hulle behandeling. Die data toon wisselende grade van besorgheid oor hakkel. Die tradisionele geloof rakende die oorsaak en behandeling van hakkel stem ooreen met die huidige menings wat gehuldig word deur spraakpataloë. Die implikasies van bevindinge word bespreek met behulp van terpeutiese riglyne, samewerking met Tradisionele Genesers en verdere navorsing.

\section{Indigenous Healers and Stuttering}

An important aspect of stuttering in relation to research and therapy is the attitude of the stutterer himself and that of his associates toward his speech symptoms. (Ammons and Johnson, 1944, p.39)

Although emotions and attitudes are highly individualistic, cultural beliefs and background will invariably influence them as "... culture is the indispensable factual background in relation to which the worker adapts his contribution to the situation before him." (Fenalson, 1952, p.4). Culture implies meanings, ideas and values that constitute a way of life that pervades relationships, systems of belief and behaviour.

It may be assumed therefore that culture will influence attitudes towards stuttering as well as its development and treatment. Wendell Johnson (1944), in his studies of American Indians, was one of the first to investigate cultural influences on stuttering. He found no evidence of stuttering and no name for it was present in the languages of the groups studied. He interpreted this lack of a name as being the reason why stuttering did not exist, because it implied that stuttering was not significant in this culture. Later analysis (Wingate, 1972) identified methodological problems in Johnson's research and his results were discredited.

Subsequent studies, cited by Van Riper (1971) found stuttering among population groups as diverse as the Japanese and Eskimo, leading him to conclude that stuttering exists universally. Therefore, the cause is unlikely to be related to cultural attitudes. He does, however, cite Kluckhohn (1954) who states that "... impressive differences in the degree and incidence (of stuttering) suggests cultural influences are operative." (Van Riper, 1971, p.9.)

Wingate (1972) attributes this to the differences in the importance and expectations of a child's speech, across cultures. This sentiment is reiterated by Snidecor (1947), Leith \& Mims (1975), Leith (1986) and Shames (1989) who identify cultural factors such as stress on speech performance, and child-rearing practices which are likely to influence the incidence of stuttering.

Having concluded that cultural beliefs influence the incidence of, and attitudes towards stuttering, and that these attitudes should be identified and explored in therapy, it is evident that the speech therapist needs to be familiar with the cultural beliefs of her clients. Shames (1989) states that "... therapy becomes an intercultural collision of values, attitudes, expectations and definitions". Owing to the disproportionate ratio of Black speech therapists to Blacks in South Africa, one is faced with a situation where the majority of trained therapists are unfamiliar with the cultural backgrounds of their clients. Current trends in therapy derive from America and Europe with an orientation not designed to meet the needs of cultures as diverse as that of Black South Africans. The success of therapy may therefore be hindered by the denial of, or failure to acknowledge a client's cultural beliefs through lack of knowledge, and his being forced to conform to those proposed by modern theories. Refuting beliefs about cause and treatment may serve only to alien- 
ate the client (Leith \& Mims, 1975). Fenalson (1952) demands that any professional worker attempting to help others in areas of personal adjustment, needs to understand an individual in terms of his culture and its effect on his responses to life experiences.

South African psychologists have become increasingly aware of the necessity to re-evaluate the therapy that they offer in terms of cultural appropriateness. Holdstock (1979, p.119) goes as far as to say that “... professionals would never be able to satisfy the emotional needs of people", while the therapy that they offer is tailored to Westernised cultures. It may be meaningless and ineffectual when applied to members of a culture so starkly different from it.

The writers have, therefore, undertaken to study an aspect of the attitudes and perceptions of a sample of Black people in South Africa to stuttering. In order to attain an understanding of traditional cultural beliefs it was decided to focus on Indigenous Healers (IHs) for this information as they have been described as "... psychologist, physician as priest ... tribal historian" (Holdstock, 1979, p.119). The IH is a highly respected member of the tribe, a reservoir of traditional beliefs and one who has the power to modify customs (Hammond-Tooke, 1989). He is that indispensable member of the society who is consulted by an estimated $70 \%$ of the black population of S.A. (Mzinyathi, undated, p.144). In 1977 the Soweto Society for Marriage and Family Life concluded that the majority of people in Soweto believe in the power of the IH (Holdstock, 1979). The World Health Organisation (WHO) estimated that IHs form the essential core of primary health workers for nine tenths of two billion rural dwellers in Third World countries (Holdstock, 1979). Once urbanised, a black person may well consult an IH as Hammond-Tooke (1974) predicts that an urban diviner's clientele consists of traditionalists, professionals, middle-class Blacks and even Whites. IHs may, therefore, be considered a valuable source of information on cultural beliefs about stuttering as well as on the traditional treatment for stuttering.

According to Hammond-Tooke (1989) there are two distinguishable types of healers, i.e. diviner and herbalist. The herbalist is one who has not been mystically called but is a master of medicines. He is one who has knowledge of plants and roots. The diviner, on the other hand has been described by Hammond-Tooke (1989, p.104) as one "... clothed with power and knowledge ... called to the profession by the prompting of the ancestors". He, therefore, likens the diviner to a doctor, and the herbalist to a pharmacist. A diviner is consulted in the case of a longlasting illness in order to establish a cause and a remedy for the illness. The diviner was, therefore, considered to be the more suitable subject for this research report.

South Africa is moving towards a new political dispensation with revised health policies. The inclusion of the IH into these policies is now under debate. The role of the IH cannot be ignored as he is accessible to and consulted by the majority of the Black people in South Africa. It is estimated that there are between $100 \sqcap 000$ and $200 \sqcup 000$ IHs practising in S.A. today (Freeman, 1992). In the best interests of the clients, Krober (1990), therefore recommends fostering a spirit of co-operation between traditional healers and medical practitioners. Holdstock (1979) agrees with this recommendation and admonishes members of the helping professions that "... although indigenous healing is as old as the civilisation of Africa and at present time adhered to by countless numbers of individuals, people in the helping professions and academic community know next-to-nothing about it and acknowledge it even less" (Holdstock, 1979, p.118). There are those (Motlana, 1992) who, on the other hand, are vehemently opposed to any co-operation. They perceive IHs as dangerous due to their lack of knowledge of physiology and anatomy. Motlana (1992) criticises any attempt to co-ordinate traditional and modern practices as he feels that it traps the South African Black person in a previous era while the rest of the community moves forward into a technologically advanced and sophisticated century.

South African speech therapists cannot make an assessment about the efficacy of traditional methods until they have a knowledge of what they comprise. Effective, efficient and meaningful therapy may then only be provided once the client's attitudes and expectations have been assessed.

\section{Methodology}

\section{Aims}

The aims of this study were twofold:

1. To probe the cultural beliefs and attitudes of $\mathbf{I H s}$ to stuttering.

2. To investigate whether they treat stuttering clients and, if so, what this treatment would comprise.

\section{Subjects}

Because of time and other practical constraints the size of the sample had to be restricted to five subjects. An attempt was made to choose subjects reflecting the population of the IHs which is divided into the Nguni, Sotho, Venda and Tsonga groups (Hammond-Tboke, 1989). Unfortunately, no Venda subject was available. Two subjects had rural, and three urban practices to reflect possible differences in approach. All subjects were diviners, as it was considered that they would be the more likely' IHs to be consulted in the event of stuttering.

All subjects were contacted through the African National Healers Association (ANHA), as Freeman (1992) cautions against consultation with IHs who may not be authentic. For a description of the individual subjects please see Table I.

\section{Procedure}

The survey was conducted through interviews because of the "richness and spontaneity of information" (Oppenheim, 1966, p.32) which is obtained through this method of data collection. Interviews yield a high response rate and decrease the number of "don't know" and "no answer" responses (Young, 1966). The flexibility of an interview was felt to be particularly appropriate in this instance as English was not the home language of any of the subjects, and it was therefore sometimes necessary to rephrase, explain and probe. Interviews do not require reading or writing ability on the part of the subjects. This was an important consideration as according to the African National Healers Association (unpublished) not all IHs are literate.

An interview is prone to a number of sources of error 
Table 1. Description of Subjects

\begin{tabular}{|c|c|c|c|c|c|c|}
\hline Subjects & $\begin{array}{l}\text { Professional } \\
\text { Name }\end{array}$ & $\begin{array}{c}\text { Years } \\
\text { in } \\
\text { Practice }\end{array}$ & $\begin{array}{l}\text { Rural/ } \\
\text { Urban }\end{array}$ & Calling & Training & Experience \\
\hline $\begin{array}{l}\text { 1. Tsonga } \\
\text { (Female) }\end{array}$ & Mungome & 22 & $\mathrm{R}$ & $\begin{array}{l}\text { Fell ill. Couldn't eat. } \\
\text { No improvement till } \\
\text { consulted Mungome } \\
\text { who told her it was a } \\
\text { calling. }\end{array}$ & $\begin{array}{l}8 \text { months with } \\
\text { Mungome. Commu- } \\
\text { nicated with ances- } \\
\text { tors in visions. }\end{array}$ & $\begin{array}{l}\text { Specialist in child- } \\
\text { hood health problems. } \\
\text { Others - infertility, } \\
\text { insomnia due to } \\
\text { witchcraft. Ulcers. } \\
\text { Trains novices. }\end{array}$ \\
\hline $\begin{array}{l}\text { 2. S. Sotho } \\
\text { (Female) }\end{array}$ & Ngaka & 22 & $\mathbf{R}$ & $\begin{array}{l}\text { Became ill. } \\
\text { Taken to IH. }\end{array}$ & $\begin{array}{l}\text { Inaugurated via } \\
\text { rituals - slaughte- } \\
\text { ring goats. Drinking } \\
\text { or smoking medi- } \\
\text { cines. }\end{array}$ & $\begin{array}{l}\text { Specialist in child- } \\
\text { hood disorders - } \\
\text { diarrhoea, vomiting, } \\
\text { swollen feet, sores } \\
\text { under tongue, nail } \\
\text { biting, failure to } \\
\text { speak. Trains novices. }\end{array}$ \\
\hline $\begin{array}{l}\text { 3. Xhosa } \\
\text { (Male) }\end{array}$ & Igquira & 7 & $\mathbf{U}$ & $\begin{array}{l}\text { Fell ill. Untreatable } \\
\text { by orthodox medicine. }\end{array}$ & $\begin{array}{l}1 \text { year under IH. } \\
\text { Gained ability to } \\
\text { communicate with } \\
\text { ancestors and to } \\
\text { predict events before } \\
\text { they occur. }\end{array}$ & $\begin{array}{l}\text { Treats mental distur- } \\
\text { bance, body sores, } \\
\text { visual defects, } \\
\text { stomach ache, female } \\
\text { problems, birth dif- } \\
\text { ficulties. }\end{array}$ \\
\hline $\begin{array}{l}\text { 4. Zulu } \\
\text { (Male) }\end{array}$ & Inyanga & 9 & $U$ & $\begin{array}{l}\text { Fell ill. Called to } \\
\text { profession by his } \\
\text { deceased grandfather. }\end{array}$ & $\begin{array}{l}1 \text { year and still } \\
\text { consults his trainer. } \\
\text { Throws bones to } \\
\text { formulate diagnosis. }\end{array}$ & $\begin{array}{l}\text { Ability to cure VD, } \\
\text { nausea, vomiting and } \\
\text { bewitching given as } \\
\text { a few examples. }\end{array}$ \\
\hline
\end{tabular}

and its scientific utility is limited. It does, however, offer a means to establish contact with the subjects and to assess the appropriateness of this source of information.

\section{Question Construction}

The order and sequencing of questions was controlled (Young, 1966). Most questions were open-ended as these provide the best opportunity to obtain the maximum amount of information from each question. Guidelines outlined in the literature (Babbie, 1973) were followed in the construction of questions.

\section{Pilot Study}

Following a pilot study, conducted with a Southern Sotho IH, several changes were made to the sequence and content of the questions. At the end of the interview the respondent asked if she could ask the interviewer some questions. This proved to be valuable as her questions provided insight into her frame of reference and beliefs about stuttering. This procedure was then incorporated into the interview framework.

\section{Interviews}

It was felt that the respondents would feel more relaxed and discuss their thoughts and practices more openly in familiar surroundings. Subjects 1 and 2, who practice in a rural area, were interviewed at a private residence of their choice in the area in which they live. The other three subjects were interviewed at the offices of the ANHA. The interviewer followed the subjects' lead in terms of where to sit, i.e. at a table or on the floor.

None of the respondents could speak English well and they were, therefore, joined by a member of the African National Healers Association (not an IH himself) who acted as interpreter. Kahn and Cannel (1957) caution against the use of an interpreter as it creates a barrier in the establishment of a rapport between respondent and interviewer. In this case it was felt that the interpreter actually set the respondents at ease and facilitated more open responses. An interpreter should merely be a medium through which questions and answers are transmitted (Young, 1966). In order to ensure this, sources of error such as prompting or leading the respondent's answers were discussed with the interpreter before the first interview. He showed a knowledge and understanding of the protocol for research.

During the third interview, the interviewer became aware that the interpreter was leading the subject. When this interview was analysed by a Sotho speaking speech therapy student her suspicions were reinforced. It was, therefore, decided to exclude this subject from the study. Following this the process was rediscussed with the interpreter and he was reminded of his role before completing the remaining two interviews.

None of the subjects was present at interviews other than their own and they were asked not to discuss their interviews with the other subjects. 


\section{Analysis of the Data}

The contents of the interviews were reported upon as "... precise summaries of the data" (Forcese and Richer, 1973, p.213). As this research was descriptive, results were categorised according to the questions, tabulated, and discussed qualitatively in order to compare the salient features.

\section{Results and Discussion}

The subjects' views on stuttering, i.e. name, cause, management, outcome and attitudes are presented in $\mathrm{Ta}-$ ble 2 , and will be discussed below.

\section{Name and Description of Stuttering}

All the IHs had names for stuttering, which corresponded with those found by Aron (1966). S1 and S2 also gave alternate names. S1 (Tsonga) originally spoke of treating "lilele", which from her description may or may not have referred to stuttering. However, when asked to translate "stuttering" she used the term "konkoretsa" and demonstrated this as syllable repetitions.

It is interesting to note the similarity between this word and "korakoretsa" the term used by S2 (South Sotho) as these two languages are not related.

All the names used were onomatopoeic as are the names for stuttering in many languages, e.g. "tuhuhtuhuh" Egyptian, "gimgeim" - Hebrew and "howdodo" - Ghana (Van Riper, 1971).

The IH's descriptions of stuttering all corresponded with the description of characteristic stuttering symptoms, i.e. syllable repetitions, complete blocks and sound prolongations given by Peters and Guitar (1991).

\section{Cause}

All 4 subjects identified stuttering as an inherited disorder, although S4 was originally undecided, Authorities in the field of speech therapy have, over the years, researched heredity as a causative factor. Theorists now seem to agree that certain constitutional factors may be inherited and predispose a child to stuttering (Van Riper, 1973; Bloodstein, 1987).

S2 and S3 gave additional causes which seem to have their roots in folklore, i.e. being left out in the first rains of spring or failure to inform the ancestors of the child's imminent birth. S2 gave witchcraft as another alternative. These have no parallel in the professional literature.

\section{Diagnosis and Management}

The subjects differed in their approaches to diagnosis and management. S1 believes there is no treatment for konkoretsa as it is hereditary. S2 treats according to the cause. Where the cause is hereditary there is usually a sore under the tongue which she treats with medication. If the stutter is caused by being left out in the rain the child must be treated outside (as this is where the affliction took place) by inhaling smoke from the ashes of medicinal products.

S3 manifests the same symptoms as the patient and through this, intuitively determines the cause and treatment. He may use prayer, ritual medication or fulfilment of the forgotten rituals. He also educates parents and siblings on ways to handle the stutterer. S4 communicates with the ancestors, then prepares medication from the dried tongues of certain animals which is rubbed into cuts in the throat.

Table 2. Summary of Data

\begin{tabular}{|c|c|c|c|c|c|c|c|}
\hline & Name & Description & Cause & Management & Outcome & $\begin{array}{l}\text { Attitude of } \\
\text { Stutterer }\end{array}$ & $\begin{array}{l}\text { Attitude of } \\
\text { Society }\end{array}$ \\
\hline $\begin{array}{l}\text { S1 } \\
\text { Tsonga }\end{array}$ & $\begin{array}{l}\text { (Lilele) } \\
\text { Konkoretsa }\end{array}$ & $\begin{array}{l}\text { Syllable } \\
\text { repetitions }\end{array}$ & $\begin{array}{l}\text { - Heredity } \\
\text { (Accumulation } \\
\text { of coagulated } \\
\text { milk in throat.) }\end{array}$ & $\begin{array}{l}\text { - None } \\
\text { - Medication }\end{array}$ & - None & $\begin{array}{l}\text { Not a } \\
\text { problem }\end{array}$ & $\begin{array}{l}\text { Accepting } \\
\text { Status } \\
\text { unaffected. }\end{array}$ \\
\hline $\begin{array}{l}\text { S2 } \\
\text { South } \\
\text { Sotho }\end{array}$ & $\begin{array}{l}\text { Kgakgametsa } \\
\text { Korakoretsa }\end{array}$ & $\begin{array}{l}\text { Syllable } \\
\text { repetitions } \\
\text { Prolongation } \\
\text { Visible and } \\
\text { audible } \\
\text { tension }\end{array}$ & $\begin{array}{l}\text { - Heredity } \\
\text { - Baby left out } \\
\text { in first spring } \\
\text { rain }\end{array}$ & $\begin{array}{l}\text { - Medication } \\
\text { - Prayer and } \\
\text { ritual medi- } \\
\text { cation. } \\
\text { - Parental } \\
\text { counselling. }\end{array}$ & $\begin{array}{l}\text { Slow speech } \\
\text { Easy prolon- } \\
\text { gations }\end{array}$ & $\begin{array}{l}\text { Problem } \\
\text { Low self } \\
\text { esteem }\end{array}$ & $\begin{array}{l}\text { Accepting } \\
\text { Status } \\
\text { unaffected. } \\
\qquad\end{array}$ \\
\hline $\begin{array}{l}\text { S3 } \\
\text { Xhosa }\end{array}$ & Thintitha & $\begin{array}{l}\text { Syllable } \\
\text { repetitions } \\
\text { Blocks }\end{array}$ & $\begin{array}{l}\text { - Heredity } \\
\text { - Failure to } \\
\text { inform ancestors } \\
\text { of imminent } \\
\text { child-birth } \\
\text { - Whitchcraft }\end{array}$ & $\begin{array}{l}\text { - Prayer } \\
\quad \text { Medication } \\
\text { Rituals } \\
\text { Parental } \\
\text { counselling } \\
\text { - As with men- } \\
\text { tal disorder }\end{array}$ & Slow speech & $\begin{array}{l}\text { Big } \\
\text { problem } \\
\text { handi- } \\
\text { capping }\end{array}$ & $\begin{array}{l}\text { Accepting } \\
\text { Status } \\
\text { unaffected }\end{array}$ \\
\hline $\begin{array}{l}\text { S4 } \\
\text { Zulu }\end{array}$ & Amalimi & $\begin{array}{l}\text { Repetitive } \\
\text { clicks } \\
\text { (syllable } \\
\text { repetitions) }\end{array}$ & - Heredity & $\begin{array}{l}\text { - Medication } \\
\text { applied to } \\
\text { cuts on throat } \\
\text { area. }\end{array}$ & Slow speech & $\begin{array}{l}\text { Big } \\
\text { problem }\end{array}$ & $\begin{array}{l}\text { Accepting } \\
\text { Status } \\
\text { affected }\end{array}$ \\
\hline
\end{tabular}




\section{Outcome}

Subjects 2,3 and 4 were agreed that their treatment would not cure the stuttering but would lead to slower, improved speech. Therapists in many parts of the world report programs based on slow easy speech as helpful for stutterers (Peters \& Guitar, 1991).

Subject 2 claimed that "there will be some noticeable change in the child". When asked to demonstrate the change, she showed easy prolongations in place of the effortful blocking she had shown as symptomatic of stuttering. Van Riper (1973) and others, advocate modifying the symptoms of stuttering to easy prolongations.

There is no objective proof that the IH's treatment of stuttering is as successful as reported. It is likely, however, that the treatment could bring relief to the patients, at least partially, through indirect suggestion. Indirect suggestion forms part of any stuttering program. A patient seeking therapy, goes with an anticipation and expectation of relief from his stuttering. This strong faith and desperate need are able to bring about a certain amount of relief (Van Riper, 1973). Van Riper attributes the success of suggestion to the intermittent, variable, fluctuating nature of stuttering, spontaneous recovery and the fact that temporary fluency is easily established.

Whether or not any known medication has proved successful in treating stuttering is queried. Van Riper (1973) cites many experiments done to assess the efficacy of certain drugs but criticizes their methodologies. He concludes that placebos may produce the same effects as drugs, because the therapeutic value of drugs often comes from the patient's faith in his physician. Van Riper (1973) gives credit for success in therapy, to the therapist's love and concern for the patient, over any other factors.

IHs provide “... warm, nurturent, total acceptance of their patients" (Hammond-Tooke, 1989, p. 147). This, coupled with a belief in their powers of healing and a need to be cured, may be effective in relieving some of the symptoms, e.g. tension, associated with stuttering.

Counselling parents also plays a significant part in the therapy provided by speech therapists. The principle of guiding parents in terms of their speech and behaviour towards a stuttering child, is reported by some of the IHs. Given the warm empathetic environment that an IH can provide, parents may discuss their anxieties and become open to suggestions regarding the treatment of their children (Van Riper, 1973). It is not uncommon for parents to report a dramatic cessation in stuttering once they have removed certain pressures from speaking situations (Van Riper, 1973). Strategies, e.g. use of simple language, reducing time pressure, providing a fluency model and not calling attention to the stutter are some of the suggestions that Peters and Guitar (1991) make reference to in a summary of the parent counselling of theorists such as Van Riper, Bloodstein and Luper and Mulder. S3 makes similar suggestions, e.g. "... they shouldn't shout at the child, they shouldn't speak fast to the child", and cautions that "... imitating him to tease him creates a big problem ... this shouldn't be done".

The success of the IHs treatment may, in some cases, not be attributable to their efforts at all. Research has indicated that $50-80 \%$ of children who stutter, recover before puberty, without any treatment (Peters and Guitar, 1991). Although they commented that the methods of gathering this information were not entirely reliable, Peters and Guitar (1991) conclude that spontaneous recovery can occur.

\section{Attitudes}

S1 did not feel that konkoretsa was a problem. The other three concluded that stuttering was a problem which would handicap the individual or cause him to develop a low self esteem. However, only S4 felt that the stutterer would be prevented from attaining a position of status such as a tribe leader. This duty requires proficient, confident speech which is beyond the reach of the stutterer.

\section{Implications}

Aron (1991) estimates that only a fraction of the more than 3000000 people in South Africa who require speech therapy, receive it, due to the small number of speech therapists working in this country. As a solution she proposes a community based approach to speech therapy, i.e. training community workers to provide basic therapy and knowledge of when and to whom referrals should be made. IHs are already recognised and consulted by most Black South Africans. They may, therefore, provide the untapped resource needed to make services accessible to more people with communication disorders, one that includes an awareness of "linguistic and cultural forces that operate" on the individual (Shames, 1989, p.74). Co-operation between speech therapists and IHs in the treatment of stuttering appears viable, not to undermine or eradicate cultural beliefs, but to share information and establish a system of referral.

The beliefs held by IHs have proven to be a fertile and accessible area and more research is indicated in

- IH's beliefs as to cause and management of other communication disorders, e.g. hearing loss, strokes and cerebral palsy were mentioned by these subjects;

- the outcome of treatment by an IH from the patient's perspective;

- interviewing greater numbers of IHs in order to generalize common trends in their beliefs about cause, management and attitudes to stuttering:

- a comparison of the views of rural and urban IHs. Although no marked differences appeared in the views expressed by the subjects in this study, it must be noted that the two rural subjects lived relatively close to an urban area. Possibly subjects living in more remote parts of the country might offer different ideas;

- the efficacy of modern stuttering therapies for Black South Africans.

\section{Conclusion}

At a conference in Geneva in 1987, the WHO resolved to develop traditional medicine in its member states as IHs constitute the most abundant health resource in many countries. In order to utilise and maximise this existing resource, the WHO has suggested national research strategies into traditional medicine (Akerele, 1987).

South Africa too is scrutinising its National Health Policy in order to address primary health needs (Aron, 1991). These could be satisfied by community workers familiar with the particular linguistic and cultural background of the community. The IH may be considered ideal 
in filling this role.

This article is limited in terms of its scope, i.e. only stuttering was investigated and only a small sample was used. However, it indicates that communication disorders are recognised and treated by IHs, and more research into this field is necessary.

Further research may strengthen the conclusion that co-operation between IHs and speech therapists is possible as “... knowledge and sympathetic understanding ... combine in ongoing dialogue, with the interests of the patient as the overriding concern" (Hammond-Tooke, 1989, p.155).

\section{Acknowledgments}

The writers wish to thank the following:

1. The African National Healers Association for assistance with information and obtaining subjects.

2. Mr Rakaluta the interpreter.

3. The subjects who participated willingly in the research and shared their knowledge generously.

\section{REFERENCES}

African National Healers Association. Unpublished paper on Research Issues and the ANHA.

Akerele, 0 . (1987). The best of both worlds: Bringing traditional medicine up to date. Soc. Sci. Med., Vol. 24, No. $2,177-181$.

Ammons, R. \& Johnson, W.(1944). Studies in the psychology of stuttering. JSD, Vol. 9, 39-393.

Aron, M. L. (1966). The nature and Incidence of Stuttering Among a Bantu Group of School going Children. JSHD, Vol. 21, No. 2, 116-128.

Aron, M. L. (1991). Perspectives. South African Journal of Communication Disorders, Vol. 38, 3-11.

Babbie, C. R. (1973). Survey Research Methods, California: Wadsworth Pub. Co.

Bloodstein, O. (1987). A Handbook on Stuttering, Chicago: National Easter Seal society.

Fenalson, A. F. (1952). Essentials in interviewing, New York: Harper \& Brothers.

Freeman, M. (1992). Lecture on the Traditional Healer at
Witwatersrand Medical School Conference, May 20.

Forcese, D. P. \& Richer, S. (1973). Social Research Methods, New Jersey: Prentice Hall, Inc.

Hammond-Tooke, W. D. (1974). The Bantu-speaking peoples of Southern Africa, (2nd Ed.) London: Routledge and Kegan Paul.

Hammond-Tooke, W. D. (1989). Rituals and Medicines, Johannesburg: A.D. Donker.

Holdstock, T. L. (1979), Indigenous healing in S.A.: A neglected potential. South African Journal of Psychology, Vol. 9, 118124.

Johnson, W. (1944). The Indians have no word for it: Stuttering in children. Quarterly Journal of Speech, Vol. 30, 330-337.

Kahn, R. L. and Cannel, C. F. (1957). Dynamics of interviewing, New York: John Wiley and Sons.

Krober, I. (1990). Indigenous healers in a future mental health system: a case for co-operation. Psychology in Society, Vol.

4, p.47-62.
Leith, W. \& Mims, H. (1975). Cultural influences in the development and treatment of stuttering. JSHD, 459-466.

Leith, W.R. (1986). Treating the stutterer with atypical cultural influences. In The Atypical Stutterer, St. Louis K. O. (Ed.), Orlando, Florida: Academic Press.

Motlana, N. (1992). Lecture on The Traditional Healer at the Witwatersrand Medical School conference May 20.

Mzinyathi, M. (undated). Mental Health Care in S.A.: A personal psychological perspective, 143-145.

Oppenheim, A. H. (1966). Questionnaire design and attitude measurement, London: Heinemann Educational Books Ltd.

Peters, T. J. \& Guitar, B. (1991). Stuttering: an integrated approach to its nature and treatment. Baltimore: Williams \& Wilkins.

Shames, G. H. (1989). Stuttering: An RFP for a cultural perspective. JFD, Vol. 14, 67-77.

Smith, T. (1991). Communicating Quality: Professional standards for speech and language therapists. Britain: The College of Speech and Language Therapists.

Snidecor, J. C. (1947). Why the Indian does not stutter. Quarterly Journal of Speech.

Van Riper, C. (1971). The Nature of Stuttering, New Jersey: Prentice Hall, Inc.

Van Riper, C. (1973). The Treatment of Stuttering, New Jersey: Prentice Hall, Inc.

Wingate, M. E. (1972). The evaluation and stuttering: II environmental stress and critical appraisal of speech. In An analysis of stuttering: Selected readings, L. L. Emerick \& C. C. Hamre (Eds.), Illinois: Interstate Publishers and Printers.

Young, P. V. (1966). Scientific social surveys and research, 4th Edition, New Jersey: Prentice Hall Inc.

\section{Appendix}

\section{Interview Format}

A) Biographical Information

1) Name, ethnic group.

2) How did you become an IH?

3) Did you receive training?

4) For how many years have you been practicing as an $\mathrm{IH}$ ?

\section{B) Stuttering}

1) Tell me about the work you do.

2) Have you ever been consulted by a patient with a speech problem? Tell me about this case.

3) Do you know what stuttering is?

4) What word do you use for stuttering?

5) Have you ever treated a stutterer?

- Cause

- Management

- Outcome

6) Does your treatment differ if the patient is male or female?

7) Would a stutterer's status be affected because of the stuttering, e.g. could he be a tribe leader?

8) How would you rate stuttering: As a big, small or no problem?

9) Do you have any questions that you would like to ask me? 